\title{
A high glucose condition sensitizes human hepatocytes to hydrogen peroxide-induced cell death
}

\author{
HIDETAKA SHIBATA $^{1}$, TATSUKI ICHIKAWA ${ }^{1}$, KAZUHIKO NAKAO $^{1}$, HISAMITSU MIYAAKI $^{1}$, \\ SHIGEYUKI TAKESHITA ${ }^{1}$, MOTOHISA AKIYAMA ${ }^{1}$, MASUMI FUJIMOTO ${ }^{1}$, SATOSHI MIUMA ${ }^{1}$, \\ SHOUGO KANDA ${ }^{2}$, HIRONORI YAMASAKI ${ }^{3}$ and KATSUMI EGUCHI ${ }^{1}$
}

\author{
${ }^{1}$ The First Department of Internal Medicine, ${ }^{2}$ Department of Clinical Pharmaceutics, and ${ }^{3}$ Health Research Center, \\ Graduate School of Biomedical Sciences, Nagasaki University, Nagasaki, Japan
}

Received December 27, 2007; Accepted February 13, 2008

\begin{abstract}
Oxidative stress is known to play a key role in the progression of liver disease, including non-alcoholic steatohepatitis (NASH), which is often accompanied by hyperglycemia. This study examined the influence of high glucose on oxidative stress-induced hepatic cell death. Hc cells, a normal human hepatocyte-derived cell line, were cultured in normal-to-high glucose (5.5-22 $\mathrm{mM}$ )-containing medium with varying concentrations $(0.01-1 \mathrm{mM})$ of hydrogen peroxide. In certain experiments, cyclosporine A (CyA), which inhibits the mitochondrial permeability transition (MPT) pore, or Z-VAD-FMK (z-VAD), a pan-caspase inhibitor, were added to the medium. Cell viability was evaluated using a colorimetric assay. The mode of cell death was determined by nuclear staining methods using Hoechst 33258 and Sytox green. Neither high glucose $(22 \mathrm{mM})$ nor $0.05-0.5 \mathrm{mM}$ of hydrogen peroxide alone killed $\mathrm{Hc}$ cells. However, a combination of the two induced cell death, causing the nuclei of $\mathrm{Hc}$ cells to become expanded rather than condensed, and the nuclear membrane to become weak. CyA, but not z-VAD, blocked cell death. These results suggest that a high glucose condition may cause human hepatocytes to undergo hydrogen peroxide-induced necrotic cell death.
\end{abstract}

Correspondence to: Dr Tatsuki Ichikawa, The First Department of Internal Medicine, Graduate School of Biomedical Sciences, Nagasaki University, 1-7-1 Sakamoto, Nagasaki 852-8501, Japan

E-mail: ichikawa@nagasaki-u.ac.jp

Abbreviations: NASH, non-alcoholic steatohepatitis; ALD, alcoholic liver disease; $\mathrm{HCV}$, hepatitis $\mathrm{C}$ virus; ROS, reactive oxygen species; CTGF, connective tissue growth factor; CyA, cyclosporine A; MPT, mitochondrial permeability transition; CypD, cyclophilin D; Tac, tacrolimus

Key words: high glucose, reactive oxygen species, hepatocyte cell death, necrosis, cyclosporine A

\section{Introduction}

Recently, oxidative stress has been recognized as the major cause of liver disease, including non-alcoholic steatohepatitis (NASH), alcoholic liver disease (ALD) and hepatitis $\mathrm{C}$ virus (HCV)-related liver disease (1). The pathogenesis of oxidative stress is currently under investigation. Reactive oxygen species such as (ROS), superoxide and hydrogen peroxide, which are induced in the normal liver, are among the causes of oxidative stress. During inflammation due to infection, activated macrophages and neutrophils undergo respiratory bursts and release ROS to destroy invading organisms $(2,3)$. This function is an important normal immune reaction to infection in the liver. Alcohol also causes increased ROS production in the liver through several metabolic pathways, and the induced ROS accelerate hepatocyte cell death $(4,5)$. In addition, metabolic syndrome, closely associated with NASH, generates ROS in the liver and other tissues (6). ROS generation resulting in abnormal mitochondrial function has been observed in NASH and oxidative stress plays a role not only in hepatic steatosis but also in hepatic fibrosis (7). HCV also causes mitochondrial damage in hepatocytes and increases ROS $(8,9)$, followed by ROS-induced hepatic steatosis $(10,11)$. Hepatic cancer in HCV transgenic mice is moreover associated with the generation of ROS (12). In short, ROS are generated with various liver diseases and influence hepatocyte and hepatic stromal cells (13). Oxidative stress has potentially important implications for the progression of liver disease.

Oxidative stress induces insulin resistance in the liver (14) and muscle (15). It is known that insulin resistance in the liver is brought on by deficiencies in insulin signaling in hepatocytes (16) and causes hyperinsulinemia, hyperglycemia and other metabolic syndrome factors. Both hyperinsulinemia and hyperglycemia were recently noted as being a cause of liver damage (17). A previous study revealed that maintaining normoglycemia by the use of insulin reduces morbidity and mortality in critically ill patients. This phenomenon is assumed to be related to the protection of hepatocyte mitochondria ultrastructure and function by normoglycemia (18). On the other hand, hyperglycemia-related cell death is observed in various cell types. For instance, high glucose has been reported to induce endothelial cell death (19), cardiac myoblast cell death 


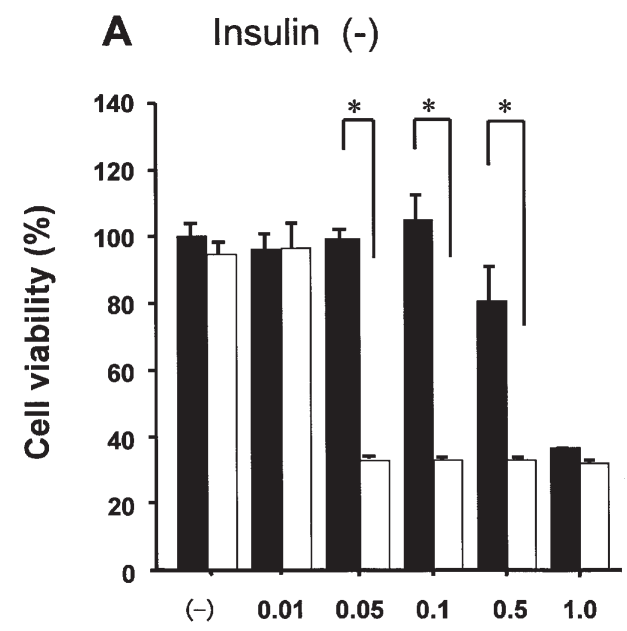

B Insulin (100 nM)

Hydrogen peroxide (mM)

Figure 1. Effect of varying concentrations of hydrogen peroxide on Hc cell viability under normal or high glucose culture conditions in the absence (A) or presence (B) of insulin. Black bars indicate a normal glucose $(5.5 \mathrm{mM})$ culture condition, and white bars a high glucose $(22 \mathrm{mM})$ culture condition. After a 2-h exposure to hydrogen peroxide $(0.01-1.0 \mathrm{mM})$, cell viability was determined using a colorimetric method. Cell viability in each culture condition is expressed as a percentage compared to the viability of the control (normal glucose medium without hydrogen peroxide and insulin). Data represent the mean \pm SD values of four independent experiments. ${ }^{*} \mathrm{p}<0.01$.
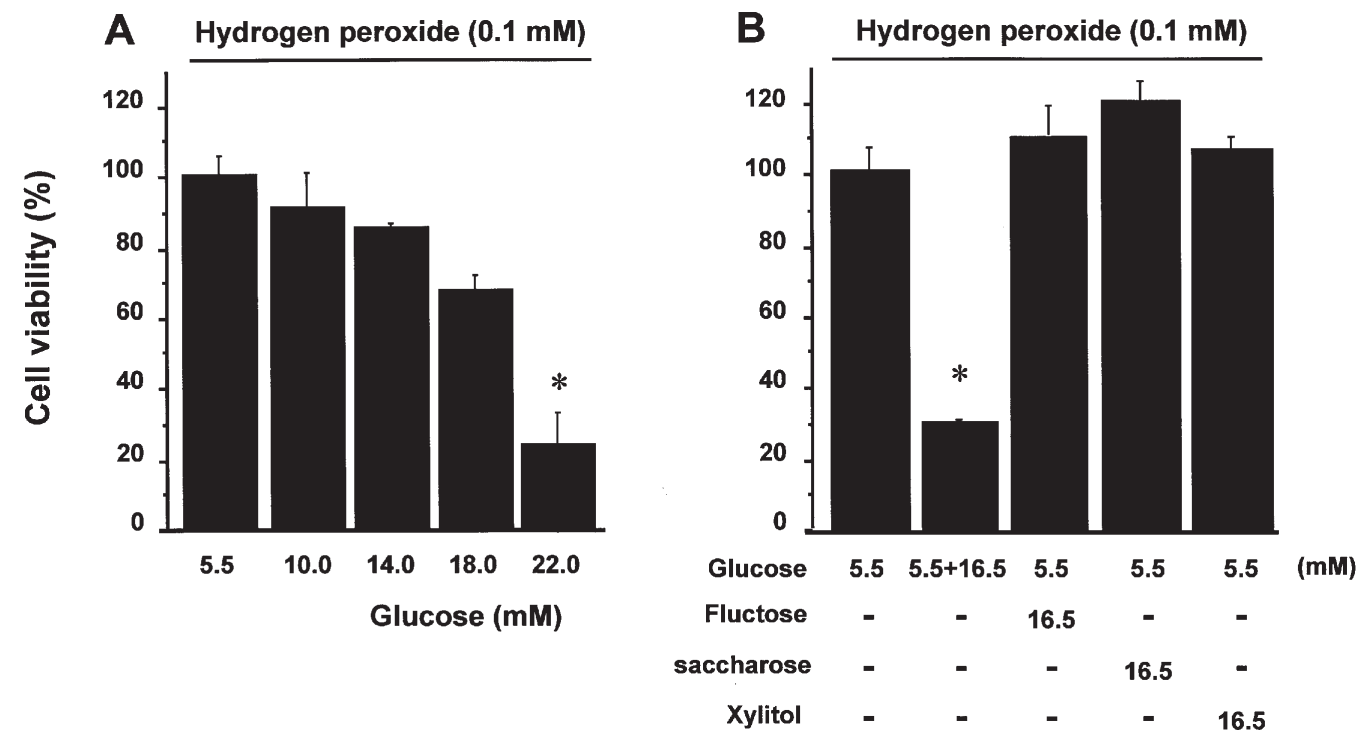

Figure 2. Effect of varying concentrations of glucose (A) and various types of saccharides (B) on hydrogen peroxide-induced Hc cell death. Hc cells were cultured in medium containing indicated concentrations of glucose with $0.1 \mathrm{mM}$ hydrogen peroxide (A). Glucose, fructose, saccharose or xylitol (17.5 mM) were added to the culture medium containing $5.5 \mathrm{mM}$ glucose with $0.1 \mathrm{mM}$ hydrogen peroxide (B). Cell viability in each culture condition is expressed as a percentage compared to the viability of the control (5.5 mM glucose medium with $0.1 \mathrm{mM}$ hydrogen peroxide). Data represent the mean $\pm \mathrm{SD}$ values of four independent experiments. ${ }^{*} \mathrm{p}<0.01$ vs. others.

(20), neuron death (21), muscle cell death (22) and podocyte cell death in vitro (23). In addition, high glucose stimulated connective tissue growth factor expression, a key factor of hepatic fibrosis, in hepatic stellate cells (24). This indicates that it might play an important role in hepatic fibrosis (25). However, the influence of high glucose on hepatocytes has not been thoroughly investigated.

Advanced liver disease by alcohol, NASH or HCV infection does not result from a single factor. The two-hit theory for the progression of NASH is a well-known hypothesis (26). Specifically, hepatic steatosis, which is correlated with oxidative stress caused by various etiologies (28), is known to be a co-factor in other liver diseases (27). A previous report demonstrated that ROS determines susceptibility to TGF- $\beta$ induced apoptosis in cirrhotic hepatocytes (29) and to TNF- $\alpha$ induced apoptosis in primary hepatocytes (30). Components of metabolic syndrome, such as hyperglycemia and hyperinsulinemia, may also be negative factors for liver disease $(31,32)$. However, the influence of the combination of metabolic syndrome and ROS on hepatocyte cell death has yet to be examined.

This study attempted to examine the influence of high glucose on ROS-induced hepatocyte cell death using hydrogen peroxide as a representative ROS. 


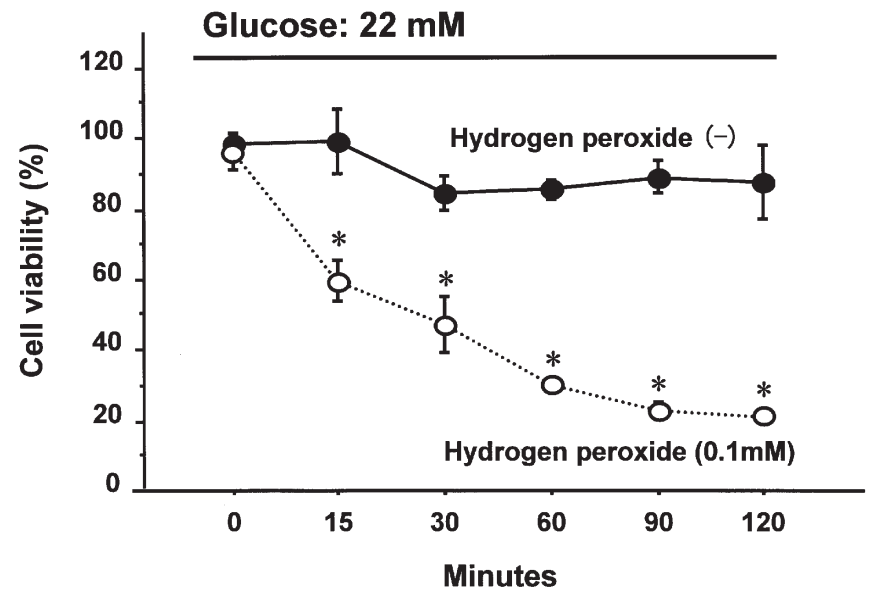

Figure 3. Time course of cell viability after exposure to high glucose with or without hydrogen peroxide. White circles indicate exposure with $0.1 \mathrm{mM}$ hydrogen peroxide, and black circles exposure without hydrogen peroxide. Cell viability is expressed as a percentage compared to the viability of the control ( $22 \mathrm{mM}$ glucose without $0.1 \mathrm{mM}$ hydrogen peroxide at $0 \mathrm{~min}$ ). Data represent the mean \pm SD values of four independent experiments. ${ }^{*} \mathrm{p}<0.01$ vs. without hydrogen peroxide at each indicated time point.

\section{Materials and methods}

Reagents and cell culture. Insulin, cyclosporine A (CyA) and tacrolimus (Tac) were generous gifts from Novartis Pharma Co. (Basel, Switzerland) and Astellas Co. (Tokyo, Japan), respectively. Z-VAD-FMK (z-VAD), a pan-caspase inhibitor, was purchased from Sigma (St. Louis, MO, USA), and hydrogen peroxide, fructose, saccharose and xylitol from Wako Pure Chemical Industries, Ltd. (Osaka, Japan).

Hc cells, a normal human hepatocyte-derived cell line, (Applied Cell Biology Research Institute, Kirkland, WA, USA) were maintained in Dulbecco's modified Eagle's medium (DMEM; Sigma) containing $5.5 \mathrm{mM}$ glucose supplemented with $10 \%$ fetal bovine serum. Cells $\left(3 \times 10^{3}\right)$ were placed into 96-well multiplates. After $8 \mathrm{~h}$, the medium was replaced with fresh serum-free DMEM containing $5.5 \mathrm{mM}$ of glucose, and the cells were incubated for $24 \mathrm{~h}$. This was followed by treatment with varying concentrations of hydrogen peroxide in serum-free DMEM containing $5.5 \mathrm{mM}$ (normal) or $22 \mathrm{mM}$ (high) glucose for 15-120 min. Next, cell viability was determined. In certain experiments, $100 \mathrm{nM}$ of insulin was added to the culture medium together with hydrogen peroxide. Varying concentrations of CyA, Tac or z-VAD were added to the culture medium $30 \mathrm{~min}$ before hydrogen peroxide treatment.

Cell viability assay. Cell viability was determined by the colorimetric method using a Cell Counting Kit (Wako Life Science, Osaka, Japan). The absorbance of each well was measured at $405 \mathrm{~nm}$ with a microtiter plate reader (Multiskan JX, Thermo BioAnalysis Co., Japan). Data were expressed as the mean \pm SD. Statistical significance was assessed using the Student's t-test. Statistically significant difference was defined as $\mathrm{p}<0.05$. All numerical results are the mean of four independent experiments.

Fluorescent nuclear staining. The Hc cells were seeded onto $11-\mathrm{mm}$ glass cover-slips in 24-well plates at $2 \times 10^{4}$ cells/well.
The next day, the medium was replaced with serum-free high or normal glucose DMEM, and the cells were treated with hydrogen peroxide. To determine the mode of cell death, Hc cells were incubated for 15 min with Sytox green nucleic acid stain (Molecular Probes, Eugene, OR, USA), which penetrates cells with compromised plasma membranes but does not cross the membranes of viable cells or apoptotic bodies. Hc cells were also stained with $1 \mathrm{mM}$ of Hoechst 33258 (Invitrogen Japan K.K., Tokyo, Japan) for $30 \mathrm{~min}$, and morphological changes in the nuclei were examined. Fluorescent nuclei were visualized using an Olympus BX50 microscope (Olympus, Tokyo, Japan) at $450-490 \mathrm{~nm}$, and images captured using a Nikon DXM 1200 digital camera (Nikon, Tokyo, Japan).

\section{Results}

High glucose enhances sensitivity in hydrogen peroxideinduced $\mathrm{Hc}$ cell death. We examined the effects of a high glucose $(22 \mathrm{mM})$ culture condition on the susceptibility of Hc cells to hydrogen peroxide (Fig. 1A). In normal glucose $(5.5 \mathrm{mM})$ culture conditions, $0.05-0.5 \mathrm{mM}$ hydrogen peroxide did not affect the viability of Hc cells. However, in high glucose $(22 \mathrm{mM})$ culture conditions, Hc cells became susceptible to $0.05-0.5 \mathrm{mM}$ hydrogen peroxide. Hydrogen peroxide $(1 \mathrm{mM})$ killed Hc cells regardless of glucose concentrations. Since insulin stimulates the uptake and metabolism of glucose in cells, we added $100 \mathrm{nM}$ insulin to the culture medium together with hydrogen peroxide (Fig. 1B). Although insulin seemed to increase cell viability in the absence of hydrogen peroxide, it could not restore the cell death induced by $0.05-0.5 \mathrm{mM}$ hydrogen peroxide in a high glucose culture condition.

Effect of glucose on Hc cell death is dose dependent; other saccharides do not have a glucose-like effect at comparable concentrations. The relationship between hydrogen peroxideinduced Hc cell death and glucose concentrations in the culture medium was examined (Fig. 2A). With $0.1 \mathrm{mM}$ of hydrogen peroxide, Hc cell viability decreased in higher glucose conditions compared to a normal glucose $(5.5 \mathrm{mM})$ condition, and considerable cell death was detected in the highest glucose conditions $(22 \mathrm{mM})$. There was a statistically significant difference between $22 \mathrm{mM}$ glucose and the other glucose concentrations $(\mathrm{p}<0.01)$. To ascertain whether this phenomenon was due to a specific effect of glucose or to non-specific effects of high concentrations of saccharides, cell viability with exposure to $0.1 \mathrm{mM}$ hydrogen peroxide was compared among similar concentrations of four different saccharides: fructose, saccharose, xylitol and glucose, where $16.5 \mathrm{mM}$ of each saccharide was added to DMEM containing $5.5 \mathrm{mM}$ of glucose to adjust the concentration (Fig. 2B). Hydrogen peroxide $(0.1 \mathrm{mM})$ induced $\mathrm{Hc}$ cell death at a high concentration of glucose only, and not at high concentrations of the other saccharides.

Hc cell viability is rapidly decreased by hydrogen peroxide in a high glucose condition. The decline of Hc cell viability was detected after $15 \mathrm{~min}$ exposure to hydrogen peroxide $(0.1 \mathrm{mM})$ in a high glucose culture condition (Fig. 3). Thereafter, cell viability rapidly decreased. Viable cells were rarely observed after $120 \mathrm{~min}$ exposure to hydrogen peroxide. 


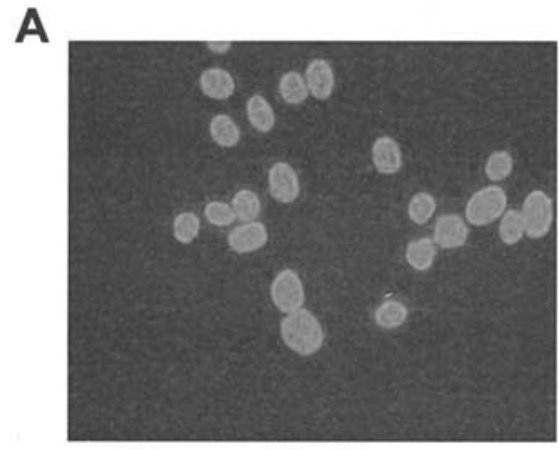

Glucose: $5.5 \mathrm{mM}$

Hydrogen peroxide: (-)

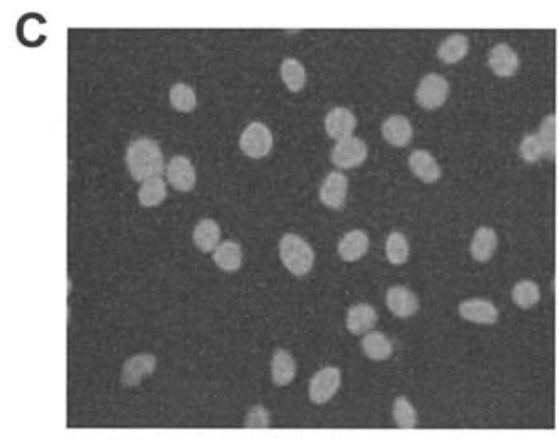

Glucose: $5.5 \mathrm{mM}$ Hydrogen peroxide: $0.1 \mathrm{mM}$
B

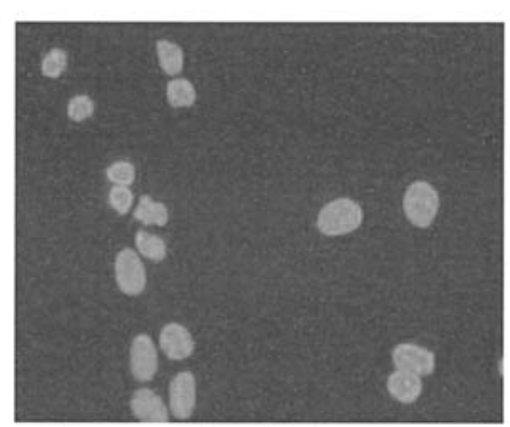

Glucose: $22 \mathrm{mM}$

Hydrogen peroxide: (-)

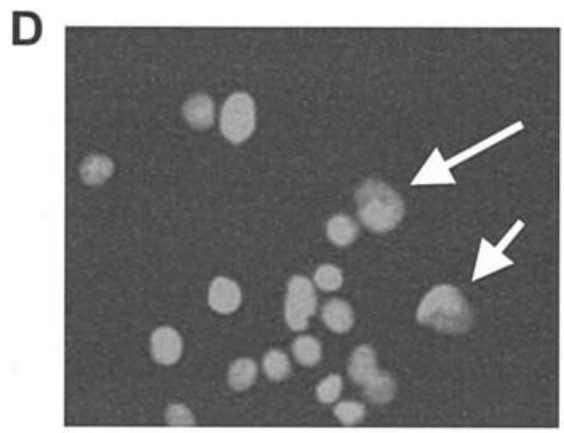

Glucose: $22 \mathrm{mM}$

Hydrogen peroxide: $0.1 \mathrm{mM}$

Figure 4. Hoechst staining of dying Hc cells. Hc cells were incubated for $120 \mathrm{~min}$ in $5.5 \mathrm{mM}$ (A) and $22 \mathrm{mM}$ (B) glucose without hydrogen peroxide, or $5.5 \mathrm{mM}$ (C) or $22 \mathrm{mM}$ (D) glucose with $0.1 \mathrm{mM}$ hydrogen peroxide, then stained by Hoechst 33258 as described in Materials and methods. Representative data from four experiments are shown.

A

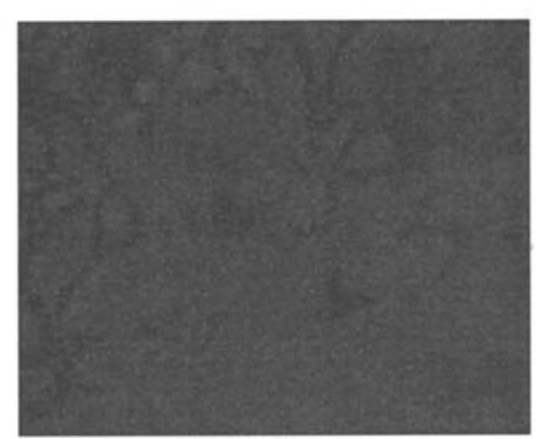

Glucose: $5.5 \mathrm{mM}$

Hydrogen peroxide: (-)

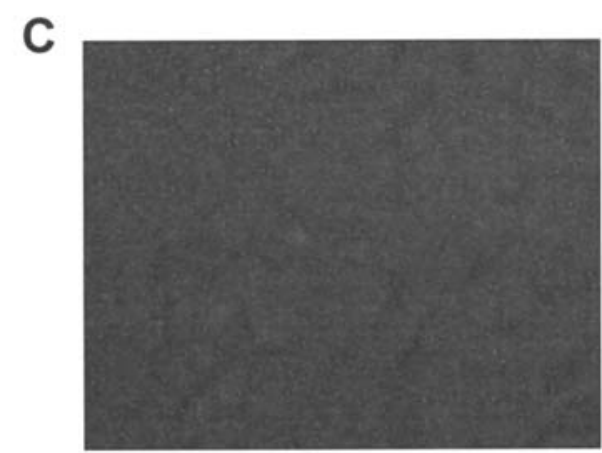

Glucose: $5.5 \mathrm{mM}$

Hvdrogen peroxide: $0.1 \mathrm{mM}$
B

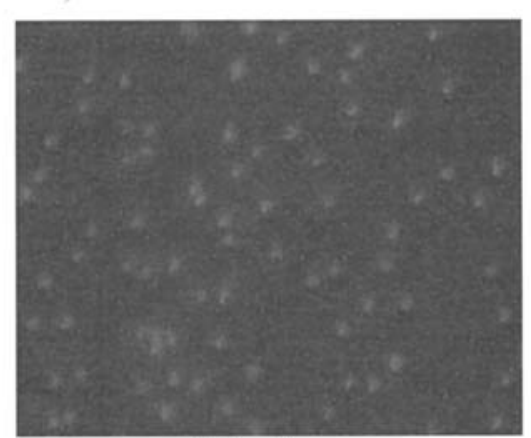

Glucose: $5.5 \mathrm{mM}$

Hydrogen peroxide: $1 \mathrm{mM}$

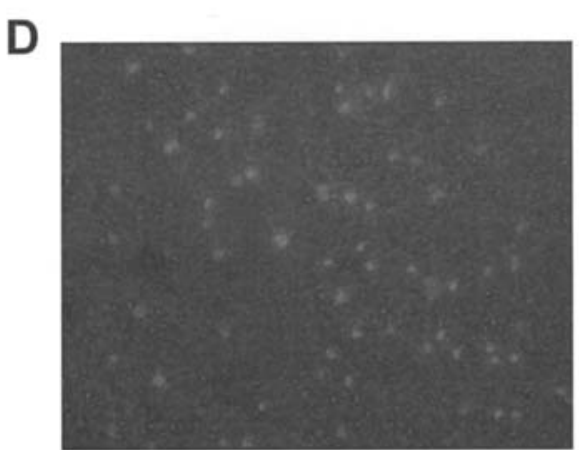

Glucose: $22 \mathrm{mM}$

Hydrogen peroxide: $0.1 \mathrm{mM}$

Figure 5. Sytox green staining of dying Hc cells. Hc cells were incubated for $120 \mathrm{~min}$ in $5.5 \mathrm{mM}$ glucose without hydrogen peroxide (A), $5.5 \mathrm{mM}$ glucose with $1 \mathrm{mM}$ hydrogen peroxide (B), $5.5 \mathrm{mM}$ glucose with $0.1 \mathrm{mM}$ hydrogen peroxide (C) or $22 \mathrm{mM}$ glucose with $0.1 \mathrm{mM}$ hydrogen peroxide (D), then stained with Sytox green as described in Materials and methods. Representative data from four experiments are shown. 
Glucose $5.5 \mathrm{mM}$

Glucose $22 \mathrm{mM}$

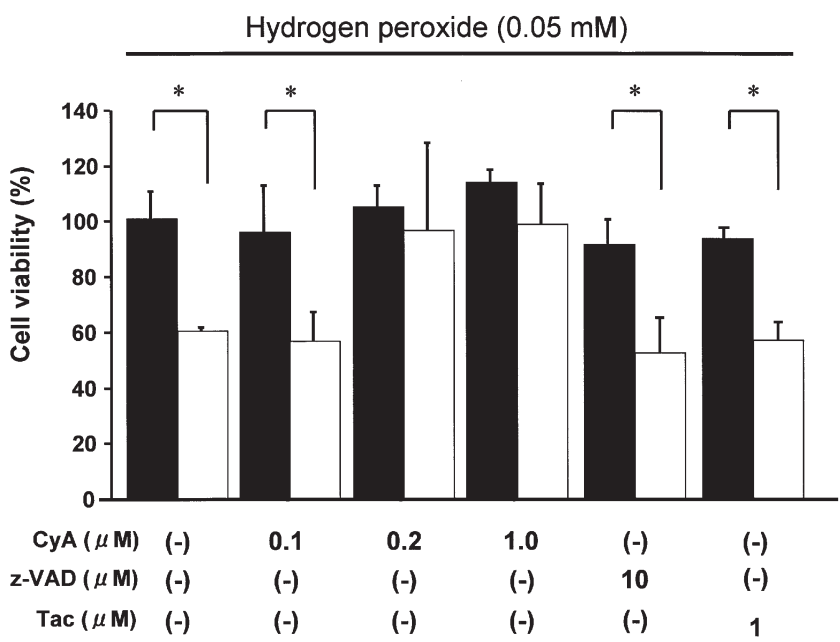

Figure 6. Effect of cyclosporine A (CyA), taclorimus (Tac) or z-VAD on cell death induced by hydrogen peroxide under high glucose conditions. Hc cells were treated for $120 \mathrm{~min}$ with $0.05 \mathrm{mM}$ hydrogen peroxide in medium containing 5.5 or $22 \mathrm{mM}$ glucose. The indicated concentrations of CyA, Tac or $\mathrm{z}$-VAD were added to the medium $30 \mathrm{~min}$ before treatment. Cell viability in each culture condition is expressed as a percentage compared to the viability of the control $(5.5 \mathrm{mM}$ glucose medium with $0.05 \mathrm{mM}$ hydrogen peroxide). Data represent the mean $\pm \mathrm{SD}$ values of four independent experiments. ${ }^{*} \mathrm{p}<0.01$

Hydrogen peroxide-treated Hc cells have enlarged and Sytox green-stained nuclei. To determine the mode of cell death, the nuclei of Hc cells were stained with Hoechst 33258 (Fig. 4) and Sytox green (Fig. 5) $2 \mathrm{~h}$ after hydrogen peroxide treatment. Hoechst 33258 staining indicated no structural changes in the nuclei of Hc cells in normal glucose, high glucose or normal glucose with hydrogen peroxide $(0.1 \mathrm{mM})$ culture conditions (Fig. 4A, B and C). However, in high glucose culture conditions, Hc cells exposed to hydrogen peroxide $(0.1 \mathrm{mM})$ showed expanded rather than condensed nuclei, indicating apoptosis (Fig. 4D). Hc cells were also stained with Sytox green, which penetrates cells with compromised plasma membranes but does not cross the membranes of apoptotic bodies. Sytox green-stained nuclei were detected in cells treated with $1 \mathrm{mM}$ hydrogen peroxide in a normal glucose condition (Fig. 5B) or with $0.1 \mathrm{mM}$ hydrogen peroxide in a high glucose condition (Fig. 5D), but not in the cells incubated in a normal glucose condition with or without $0.1 \mathrm{mM}$ of hydrogen peroxide (Fig. 5A and C).

Cyclosporine A, but not z-VAD or tacrolimus, rescues $\mathrm{Hc}$ cells from hydrogen peroxide-induced cell death. We finally examined whether CyA or z-VAD restores Hc cell death induced by $0.05 \mathrm{mM}$ of hydrogen peroxide in a high glucose condition. CyA, an inhibitor of calcineurin, has a property which inhibits mitochondrial permeability transition (MPT) pores, resulting in the inhibition of necrotic cell death (33). z-VAD, a pan-caspase inhibitor, blocks caspase-dependent cell death such as apoptosis. Pre-incubation with 0.2 and $1.0 \mu \mathrm{M}$ of CyA $30 \mathrm{~min}$ before exposure to $0.05 \mathrm{mM}$ hydrogen peroxide in a high glucose condition recovered cell viability to the level observed in $0.05 \mathrm{mM}$ hydrogen peroxide in a normal glucose concentration, but z-VAD did not (Fig. 6). Tac, another calcineurin inhibitor that does not affect MPT activity, showed no effect on cell viability.

\section{Discussion}

Several mechanisms of cell death in response to hydrogen oxide have been proposed (34-38). Of these, Peiro et al reported that a high concentration of hydrogen oxide induces necrosis and a low one apoptosis in human aortic smooth muscle cells (38). Han et al showed that sub-lethal levels of hydrogen oxide sensitized cultured hepatocytes to TNFinduced apoptosis. High levels of hydrogen oxide triggered necrosis in hepatocytes regardless of whether TNF was present (34). In the present study, 0.05-0.1 $\mathrm{mM}$ of hydrogen peroxide did not have the ability to kill Hc cells under normal glucose culture conditions. However, in a high glucose culture condition, they effectively induced Hc cell death. This cell death was characterized by rapid induction, the expansion of nuclei (39), weakness of the nuclear membrane (40), no condensation of nuclei and no restoration of cell death by a pan-caspase inhibitor. These results suggest that the mode of cell death observed in this study could be necrosis rather than apoptosis (41). In addition to the above findings, the synergic effect of high glucose and hydrogen peroxide on cell death was blocked by CyA. Since CyA inhibits MPT pores, it is possible that the mechanism of cell death was MPT dependent. CyA also inhibited Hc cell death induced by a high concentration of hydrogen peroxide (1 $\mathrm{mM}$ ) (data not shown). A similar observation was reported regarding high glucoseinduced endothelial cell death through a MPT-dependent process, which was prevented in the presence of CyA (42). These findings suggest a synergistic mechanism where high glucose induces the inhibition of MPT activity, while the addition of low-dose hydrogen peroxide leads to MPT-related cell death. A high glucose condition might elevate the sensitivity of hepatocytes to ROS, including hydrogen peroxide. This is consistent with the observation reported by Bouvard et al that HeLa-tat cells, which are stably transfected with the tat gene from human immunodeficiency virus type 1 and have a decreased antioxidant potential, exhibit necrosis or apoptosis under high glucose $(20 \mathrm{mM})$ culture conditions, while parental HeLa cells do not (42).

The relationship between CyA and cell death was recently clarified. Necrosis involves the opening of pores in the inner mitochondrial membrane, known as MPT pores (44). This process is triggered by the accumulation of calcium inside the mitochondria and an increase in oxygen-free radicals that accompanies reperfusion (45). MPT pores have three components, adenine nucleotide translocase, voltage-dependent anion transporter and cyclophilin D (CypD). CyA binds to CypD, preventing it from binding to the adenine nucleotide translocase and strongly inhibiting MPT activity (46), which leads to ATP depletion and necrotic cell death (47). MPT is a key in necrotic cell death caused by oxidative stress, but is rarely involved in apoptosis. The mechanism by which CyA inhibits MPT has been attributed to its inhibitory effect on the peptidyl-prolyl isomerse activity of CypD, believed to be required for the formation of the MPT complex and MPT activation (46). 
The coexistence of high glucose and hydrogen peroxide is a situation of clinical importance. A previous report (24) revealed that the association of elevated liver enzymes and postprandial hyperglycemia is adequate for the early diagnosis of NASH (48). Additionally, it was reported that acarbose (49), an $\alpha$-glucosidase inhibitor, improves postprandial hyperglycemia by delaying the absorption of glucose. In addition, a $ß$-cell stimulator improves postprandial hyperglycemia by early stimulation of insulin and attenuates NASH. It is possible that hepatocytes escape cell death due to the improvement of postprandial hyperglycemia provided by these drugs. However, the influence of glucose concentrations on liver disease has not been thoroughly investigated. CyA, a useful immunosuppressant, might be suitable for immunosuppression following liver transplantation. This is because transplanted patients are susceptible to diabetes (50), and liver grafts are exposed to oxidative stress such as ischemic-reperfusion stress (51), suggesting that the damaged grafted liver, along with hyperglycemia, increases the risk of hepatocyte death.

This study demonstrated that the combination of high glucose and hydrogen peroxide causes necrotic hepatocyte death. This necrotic cell death is thought to be a MPT-related cell death because it is blocked by CyA. Clinically, hyperglycemia, a factor of metabolic syndrome, is often associated with ROS in the liver. Therefore, it is necessary to examine the influence of glucose concentrations on patients with $\mathrm{HCV}$ infection, NASH and ALD and who are undergoing liver transplantation.

\section{References}

1. Mates JM: Effects of antioxidant enzymes in the molecular control of reactive oxygen species toxicology. Toxicology 153 : 83-104, 2000.

2. Jaeschke H: Preservation injury: mechanisms, prevention and consequences. J Hepatol 25: 774-780, 1996.

3. Forman HJ and Torres M: Reactive oxygen species and cell signaling: respiratory burst in macrophage signaling. Am J Respir Crit Care Med 166: S4-S8, 2002.

4. Bailey SM and Cunningham CC: Acute and chronic ethanol increases reactive oxygen species generation and decreases viability in fresh, isolated rat hepatocytes. Hepatology 28: 1318-1326, 1998.

5. Garcia-Ruiz C and Fernandez-Checa JC: Mitochondrial glutathione: hepatocellular survival-death switch. J Gastroenterol Hepatol 21 (Suppl 3): 3-6, 2006.

6. Lonardo A, Adinolfi LE, Loria P, Carulli N, Ruggiero G and Day CP: Steatosis and hepatitis $C$ virus: mechanisms and significance for hepatic and extrahepatic disease. Gastroenterology 126: 586-597, 2004.

7. Mehta K, van Thiel DH, Shah N and Mobarhan S: Non-alcoholic fatty liver disease: pathogenesis and the role of antioxidants. Nutr Rev 60: 289-293, 2002.

8. Korenaga M, Wang T, Li Y, Showalter LA, Chan T, Sun J and Weinman SA: Hepatitis $C$ virus core protein inhibits mitochondrial electron transport and increases reactive oxygen species (ROS) production. J Biol Chem 280: 37481-37488, 2005.

9. Okuda M, Li K, Beard MR, Showalter LA, Scholle F, Lemon SM and Weinman SA: Mitochondrial injury, oxidative stress, and antioxidant gene expression are induced by hepatitis $\mathrm{C}$ virus core protein. Gastroenterology 122: 366-375, 2002.

10. Valgimigli M, Valgimigli L, Trere D, Gaiani S, Pedulli GF, Gramantieri L and Bolondi L: Oxidative stress EPR measurement in human liver by radical-probe technique. Correlation with etiology, histology and cell proliferation. Free Radic Res 36: 939-948, 2002.

11. Alonzi T, Agrati C, Costabile B, Cicchini C, Amicone L, Cavallari C, Rocca CD, Folgori A, Fipaldini C, Poccia F, Monica NL and Tripodi M: Steatosis and intrahepatic lymphocyte recruitment in hepatitis $\mathrm{C}$ virus transgenic mice. J Gen Virol 85: 1509-1520, 2004.
12. Koike K, Moriya $\mathrm{K}$ and Kimura S: Role of hepatitis $\mathrm{C}$ virus in the development of hepatocellular carcinoma: transgenic approach to viral hepatocarcinogenesis. J Gastroenterol Hepatol 17: 394-400, 2002.

13. Sanchez A, Factor VM, Espinoza LA, Schroeder IS and Thorgeirsson SS: In vitro differentiation of rat liver derived stem cells results in sensitization to TNFalpha-mediated apoptosis. Hepatology 40: 590-599, 2004.

14. Ito Y, Oumi S, Nagasawa T and Nishizawa N: Oxidative stress induces phosphoenolpyruvate carboxykinase expression in H4IIE cells. Biosci Biotechnol Biochem 70: 2191-2198, 2006.

15. Khamaisi M, Kavel O, Rosenstock M, Porat M, Yuli M, Kaiser N and Rudich A: Effect of inhibition of glutathione synthesis on insulin action: in vivo and in vitro studies using buthionine sulfoximine. Biochem J 349: 579-586, 2000.

16. Schattenberg JM, Wang Y, Singh R, Rigoli RM and Czaja MJ: Hepatocyte CYP2E1 overexpression and steatohepatitis lead to impaired hepatic insulin signaling. J Biol Chem 280: 9887-9894, 2005.

17. Viberti G: Thiazolidinediones-benefits on microvascular complications of type 2 diabetes. J Diabetes Complications 19: 168-177, 2005.

18. Vanhorebeek I, De Vos R, Mesotten D, Wouters PJ, De Wolf-Peeters C and van den Berghe G: Protection of hepatocyte mitochondrial ultrastructure and function by strict blood glucose control with insulin in critically ill patients. Lancet 365: 53-59, 2005.

19. Lorenzi M, Cagliero E and Toledo S: Glucose toxicity for human endothelial cells in culture. Delayed replication, disturbed cell cycle, and accelerated death. Diabetes 34: 621-627, 1985.

20. Cai L, Li W, Wang G, Guo L, Jiang Y and Kang YJ: Hyperglycemia-induced apoptosis in mouse myocardium: mitochondrial cytochrome C-mediated caspase-3 activation pathway. Diabetes 51: 1938-1948, 2002.

21. Vincent AM, Stevens MJ, Backus C, McLean LL and Feldman EL: Cell culture modeling to test therapies against hyperglycemiamediated oxidative stress and injury. Antioxid Redox Signal 7: 1494-1506, 2005.

22. Fiordaliso F, Leri A, Cesselli D, Limana F, Safai B, NadalGinard B, Anversa P and Kajstura J: Hyperglycemia activates p53 and p53-regulated genes leading to myocyte cell death. Diabetes 50: 2363-2375, 2001.

23. Susztak K, Raff AC, Schiffer M and Bottinger EP: Glucoseinduced reactive oxygen species cause apoptosis of podocytes and podocyte depletion at the onset of diabetic nephropathy. Diabetes 55: 225-233, 2006.

24. Paradis V, Perlemuter G, Bonvoust F, Dargere D, Parfait B, Vidaud M, Conti M, Huet S, Ba N, Buffet C and Bedossa P: High glucose and hyperinsulinemia stimulate connective tissue growth factor expression: a potential mechanism involved in progression to fibrosis in nonalcoholic steatohepatitis. Hepatology 34: 738-744, 2001.

25. Sugimoto R, Enjoji M, Kohjima M, Tsuruta S, Fukushima M, Iwao M, Sonta T, Kotoh K, Inoguchi T and Nakamuta M: High glucose stimulates hepatic stellate cells to proliferate and to produce collagen through free radical production and activation of mitogen-activated protein kinase. Liver Int 25: 1018-1026, 2005.

26. Wanless IR and Shiota K: The pathogenesis of nonalcoholic steatohepatitis and other fatty liver diseases: a four-step model including the role of lipid release and hepatic venular obstruction in the progression to cirrhosis. Semin Liver Dis 24: 99-106, 2004.

27. Powell EE, Jonsson JR and Clouston AD: Steatosis: co-factor in other liver diseases. Hepatology 42: 5-13, 2005.

28. Browning JD and Horton JD: Molecular mediators of hepatic steatosis and liver injury. J Clin Invest 114: 147-152, 2004.

29. Raval J, Lyman S, Nitta T, Mohuczy D, Lemasters JJ, Kim JS and Behrns KE: Basal reactive oxygen species determine the susceptibility to apoptosis in cirrhotic hepatocytes. Free Radic Biol Med 41: 1645-1654, 2006.

30. Chen L, Kwong M, Lu R, Ginzinger D, Lee C, Leung L and Chan JY: Nrf1 is critical for redox balance and survival of liver cells during development. Mol Cell Biol 23: 4673-4686, 2003.

31. Bedogni G, Miglioli L, Masutti F, Tiribelli C, Marchesini G and Bellentani S: Prevalence of and risk factors for nonalcoholic fatty liver disease: the Dionysos nutrition and liver study. Hepatology 42: 44-52, 2005

32. Adams LA, Angulo P, Abraham SC, Torgerson H and Brandhagen D: The effect of the metabolic syndrome, hepatic steatosis and steatohepatitis on liver fibrosis in hereditary hemochromatosis. Liver Int 26: 298-304, 2006. 
33. Lemasters JJ, Nieminen AL, Qian T, Trost LC, Elmore SP, Nishimura Y, Crowe RA, Cascio WE, Bradham CA, Brenner DA and Herman B: The mitochondrial permeability transition in cell death: a common mechanism in necrosis, apoptosis and autophagy. Biochim Biophys Acta 1366: 177-196, 1998.

34. Han D, Hanawa N, Saberi B and Kaplowitz N: Hydrogen peroxide and redox modulation sensitize primary mouse hepatocytes to TNF-induced apoptosis. Free Radic Biol Med 41: 627-639, 2006

35. Gechev TS and Hille J: Hydrogen peroxide as a signal controlling plant programmed cell death. J Cell Biol 168: 17-20, 2005.

36. Daroui P, Desai SD, Li TK, Liu AA and Liu LF: Hydrogen peroxide induces topoisomerase I-mediated DNA damage and cell death. J Biol Chem 279: 14587-14594, 2004.

37. Ren D, Yang H and Zhang S: Cell death mediated by MAPK is associated with hydrogen peroxide production in Arabidopsis. $\mathrm{J}$ Biol Chem 277: 559-565, 2002.

38. Peiro C, Lafuente N, Matesanz N, Cercas E, Llergo JL, Vallejo S, Rodriguez-Manas L and Sanchez-Ferrer CF: High glucose induces cell death of cultured human aortic smooth muscle cells through the formation of hydrogen peroxide. Br J Pharmacol 133: 967-974, 2001.

39. Pozarowski P, Halicka DH and Darzynkiewicz Z: NF-kappaB inhibitor sesquiterpene parthenolide induces concurrently atypical apoptosis and cell necrosis: difficulties in identification of dead cells in such cultures. Cytometry A 54: 118-124, 2003.

40. Conde de la Rosa L, Schoemaker MH, Vrenken TE, BuistHoman M, Havinga R, Jansen PL and Moshage H: Superoxide anions and hydrogen peroxide induce hepatocyte death by different mechanisms: involvement of JNK and ERK MAP kinases. J Hepatol 44: 918-929, 2006.

41. Simm A, Bertsch G, Frank H, Zimmermann U and Hoppe J: Cell death of AKR-2B fibroblasts after serum removal: a process between apoptosis and necrosis. J Cell Sci 110: 819-828, 1997.
42. Bouvard S, Faure P, Roucard C, Favier A and Halimi S: Characterization of free radical defense system in high glucose cultured HeLa-tat cells: consequences for glucose-induced cytotoxicity. Free Radic Res 36: 1017-1022, 2002.

43. Detaille D, Guigas B, Chauvin C, Batandier C, Fontaine E, Wiernsperger $\mathrm{N}$ and Leverve $\mathrm{X}$ : Metformin prevents high-glucoseinduced endothelial cell death through a mitochondrial permeability transition-dependent process. Diabetes 54: 2179-2187, 2005.

44. Vande Velde C, Cizeau J, Dubik D, Alimonti J, Brown T, Israels S, Hakem R and Greenberg AH: BNIP3 and genetic control of necrosis-like cell death through the mitochondrial permeability transition pore. Mol Cell Biol 20: 5454-5468, 2000

45. Halestrap AP: Calcium, mitochondria and reperfusion injury: a pore way to die. Biochem Soc Trans 34: 232-237, 2006.

46. Nakagawa T, Shimizu S, Watanabe T, Yamaguchi O, Otsu K, Yamagata $\mathrm{H}$, Inohara $\mathrm{H}$, Kubo $\mathrm{T}$ and Tsujimoto $\mathrm{Y}$ : Cyclophilin D-dependent mitochondrial permeability transition regulates some necrotic but not apoptotic cell death. Nature 434: 652-658, 2005.

47. Kim JS, He L and Lemasters JJ: Mitochondrial permeability transition: a common pathway to necrosis and apoptosis. Biochem Biophys Res Commun 304: 463-470, 2003.

48. Gholam PM, Flancbaum L, Machan JT, Charney DA and Kotler DP: Nonalcoholic fatty liver disease in severely obese subjects. Am J Gastroenterol 102: 399-408, 2007.

49. Lieber CS, Leo MA, Mak KM, Xu Y, Cao Q, Ren C, Ponomarenko A and De Carli LM: Acarbose attenuates experimental non-alcoholic steatohepatitis. Biochem Biophys Res Commun 315: 699-703, 2004.

50. John PR and Thuluvath PJ: Outcome of patients with new-onset diabetes mellitus after liver transplantation compared with those without diabetes mellitus. Liver Transpl 8: 708-713, 2002.

51. Burke A, FitzGerald GA and Lucey MR: A prospective analysis of oxidative stress and liver transplantation. Transplantation 74: 217-221, 2002. 